\title{
Income Policy in the Country Under Transition - Some Remarks
}

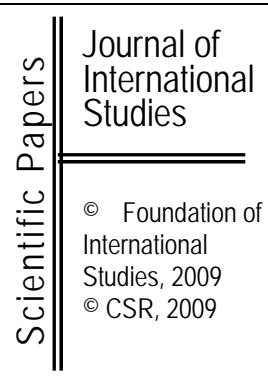

\author{
Bartosz Godziszewski \\ Faculty of computer science and management \\ Poznan University of Technology \\ bartosz.godziszenuski@put.poznan.pl
}

\begin{abstract}
Incomes policy issues have been widely discussed in modern economics. The income policy in its "classical" meaning was treated as counter inflation strategy which contrary to monetarist attitude allowed to curb inflation without causing rise in unemployment. It mainly based on wages and prices controls. However in case of country under transition meaning of this term is much wider than prices and wages control. One has to notify that much bigger number of people that in case of western economies has income from state financed pension and social security systems. The main aim of this paper is to show differences between definitions of incomes policy in its classical meaning and solutions proposed by polish Authors. This is very for analysis of economic policy in countries under transition.
\end{abstract}

Accepted: May, 2009

Keywords: Incomes policy, transition, pension system, social security.

JEL classification: H55, P2, P51

\section{Introduction}

The main aim of the paper is to present basic issues of incomes policy it the field of economy under transition. It hast to be notified that it has a different meaning that common understanding of it. Incomes policy is quite complicated issue. In its primary formula it was aimed at stopping high inflation without causing negative situation on labor market. It stemmed from criticism of monetary attitude towards stabilization issues and was widely discussed in many articles. One of very interesting explanations of need for incomes policy can be found in Sydney's Weintraub work in which he questioned various assumptions of monetarism, and suggested that wages and prices control may be a remedial measure to inflation .

\section{Incomes policy-an overlook}

However in order to understand meaning this term in case of economics under transition a much wider definition has to be adopted. According to S. Kessler and J.Robinson, one can say that there's no clear incomes policy definition in the economic

\footnotetext{
${ }^{1}$ S. Weintraub, TIPs against Inflation, [w:] An incomes policy for the United States, ed. M.P. Claudon, R.P. Cornwall, Martinus Nijhoff Publishing, Boston, 1981 P. 20-22.
} 
literature. However one can say that every economic policy that meets three below mentioned criterions simultaneously can be called incomes policy : ${ }^{2}$

- Policy is directly aimed at incomes

- There are procedures and means that Allows conducting such policy

- There must exist public interest that explains direct intervention into incomes formation a .

Considering this one can make difference between direct and indirect incomes policy

One of founders of the idea of Incomes policy is British economist R. Layard, who recommended it as a tool of stabilization of labor market .He assumed that it is very effective against incomes dispersion and should allow to create a situation in which wages of low paid employees rise faster than those from upper level. ${ }^{3}$ This is very important when public support for ant inflation Policy is required. ${ }^{4}$ Such policy can significantly raise acceptance of incomes policy directly aimed at wages.

A bit different attitude towards income policy is presented by C. R. Bean. He underlines that however commonly, incomes policy is treated mainly as ant inflation tool, it should be rather interpreted as a tool aimed at reducing wage pressure in order to reduce rate of equilibrium unemployment ${ }^{5}$. One can state that in this case incomes policy is element of labor market stabilization. On the other side author suggests that incomes policy can be effective in short run global demand and stimulation .

It has to be said that incomes policy can have direct and indirect form. In the first case it has form of influencing incomes either by taxes or by transfers aimed at entitled benefiters. Indirect incomes policy is intended to subside chosen types of public services which results in bigger consumption of agents. In some cases incomes policy is interpreted as monetary policy, especially in case of interest rates . According to S. Borkowska publications there are three main facets of incomes policy : ${ }^{6}$

- Regulations aimed at curbing pro inflationary wages increase;

- Prevention against inequality ;

- Guarantees of minimal social security (especially minimal wage regulations).

On the basis of above mentioned definitions one can say that assessing influence of incomes Policy on the economy is very complicated, due to its wide targets. Moreover above mentioned definitions are aimed at equality of incomes distribution, which are questioned by many researchers involved in the analysis of incomes policy. Many of them underlines stabilizing role of incomes policy.

According to stabilizing attitude towards incomes policy one can state that incomes policy aimed at both wages and transfers $\mathrm{s}$ has indirect influence on global demand and all economic variables that affect economic equilibrium in the short and medium run ${ }^{7}$ This fact implies that results of incomes policy are transmitted to economic growth inflation and global costs .

Very similar attitude towards incomes policy is proposed by polish author J. Adam , who defines it as „All institutions aimed at direct influence on wages' changes in order to curb inflation or preventing against it. Its main target is price stability It also has significant

\footnotetext{
${ }^{2}$ S. Kessler, Incomes Policy, British Journal of Industrial Relations, Vol .32 nr 2, June 1994, p.181.

${ }^{3}$ O. Ashenfelter, R. Layard, Incomes policy and Wage differentials , "Economica", may 1983, pp.127.

${ }^{4}$ Ibidem. p.139.

${ }^{5} \mathrm{Ch}$. R. Bean, The role of demand policies in reducing unemployment. [in]: Unemployment policy :government options for the labor market ed. D. Snower, G. de la Dehesa, Cambridge University Press, 1997, p. 103 .

${ }^{6}$ S. Borkowska, System wynagrodzeń w skali makro, Instytut Pracy i Spraw Socjalnych, Socjalnych, z. 10. Warszawa 1991, p.58.

${ }^{7}$ R. Barczyk, Teoria i praktyka polityki antycyklicznej, AE Poznań 2004, p.207.
} 
role in reducing inflationary expectations. It doesn't require unemployment causing methods ,8

One can say that this definition also underlines stabilizing facets o incomes, but in case when politicians want to reduce rate of unemployment, or at least avoid rise of it.

Very interesting interpretation of incomes policy was presented by J. Meller in his paper However his attitude reduces incomes policy to wages policy it shows number of reasons why this policy can be used as a tool of macroeconomic policy.In this case author presents a number of market imperfections that should be corrected by incomes policy. The main aim of incomes policy is either combating or reducing negative influence of these imperfections on equlibruim state. Author presents a list of incomes policy targets and reasons that supports need of using incomes policy tools. This list is very long and presents many reasons for using incomes policy and targets of it, the most important of them are $\quad:{ }^{9}$

- Prevention against excessive rise of wages, that exceeds increase of labor productivity . This situation leads to inflationary pressures, which are obviously negative ;

- Need for sustaining of honest competition between employers. In case of adverse conditions on labor market some enterprises may be interested in improving their price competitiveness at a cost of their employees ;

- Creating conditions for assuring living wage for employees and their families, so it can meet their consumption demand. Lack of living wages, even in case of well developed market economies, can result in the long run severe conflicts between employers and employees which can negatively afford economic growth ;

- Providing proper demand volume on internal market, because it influences general condition of economy and may have stabilizing role ;

- Assuring proper, stable relationships between increase of wages and labor productivity, when equilibrium in foreign trade is considered ;

- Protecting against too sharp rise in wages. Wage is a labor cost so too much rise of it may negatively affect creation of new jobs ;

- Reducing inequality of wages in case of persons employed at similar positions, which can result in frustration and enforcing extraordinary migrations on labor market.

The above described attitude towards incomes policy is very complex because it underlines not only social aspects of it but also very wide bundle of stabilizing tasks . Targets of Incomes policy are not only refer to internal market but also include foreign trade. This attitude shows number of targets that may be chosen for incomes Policy

Very wide attitude towards incomes policy is presented in by B. Szopa attitude. In this case policy can be aimed at two big areas. ${ }^{10}$ One element of incomes policy is influencing incomes formation and the other affecting price level and taxation influencing situation of chosen agents. Adopting this classification incomes policy is comprised not only of wage controls but also price controls referring to price formation mechanisms in the enterprises .

Very important issue in defining incomes policy is its subject. Initially main element of incomes were wages, but along with growing role of capital markets and greying of population role of them diminished. Over time bigger number of people achieved Incomes form Stock Exchange, pensions and various social security benefits. This was caused by rising scale of incomes redistribution. B. Winiarski presents a variety of incomes that may be

\footnotetext{
8 J. Adam Inflacja a bezrobocie. „Ekonomista” nr 4-6, 1991, p. 499.

9 J. Meller , Makroekonomiczna polityka wynagrodzeń w gospodarce rynkowej, „Praca i zabezpieczenie społeczne", nr 10/11 1992, p.8

10 B.Szopa , Polityka dochodowa na tle rynku pracy w Polsce w warunkach transformacji systemowej, AE Kraków 1997, p. 9
} 
subject to incomes policy institutions: ${ }^{11}$

- wages,

- farmers incomes,

- social benefits,

- other incomes ( scholarships, foreign transfers ).

So defined Incomes allows to see how wide can be incomes policy and how sophisticated can be tools of it. Assuming that all transfers are also subject to incomes policy activity one can say that huge parts of Common Agriculture Policy in EU, or subsidies to farm production in the US, can be treated as incomes policy because their main aim is to sustain farmers incomes. This problem is one of the most important obstacles to international trade liberalization, due to unwillingness of US, EU and Japan to design of subsiding agriculture. Of course the importance of this issue depends on share of rural areas in the total population, however even in case of countries with relatively low share this policy plays important role.

Analysis of situation of well developed economies and countries under transition show that role of incomes policy has to be changed. This stems from the fact that growing number of older people bases on incomes from social security systems, so the incomes policy should definition should be redefined .

On the basis on the above mentioned analysis author proposes a New definition of incomes policy: incomes Policy are all activities, both direct and in direct, Aimed at influencing wages and social transfers regardless of target of it.

Figure 1. Stabilization role of incomes policy

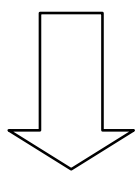

Real sector
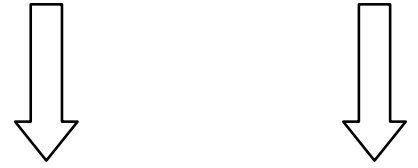

Assuring equal incomes distribution
Social goals

Labor market stabilization<smiles>C=[Tl]</smiles>

indirect<smiles>C1CCCCC1</smiles>

Money sector

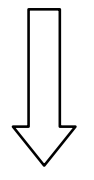

Anti inflationary goals

Source: author's own research

${ }^{11}$ B. Winiarski, Polityka gospodarcza, PWN Warszawa 2006, p. 422. 
It is very important because in much bigger number of people bases on various types of social transfers

On the presented above graph two main areas of incomes policy are presented. One is stabilizing price level this refers to a wages-prices control. Another very important and much more complicated area is stabilizing real sector. First issue is assuring equal incomes distribution, however there's no definition of equality of incomes distribution. However in case of economic policy in some countries such as Brazil economists underlines negative results of economic policy aimed at curbing inflation, which result in worsening economic situation of low paid employees and suggest that it can have negative influence on economic development. ${ }^{12}$

Another goals for incomes policy are social issues. They can be divided between working population and retired employees. In the case of working people main aim of incomes policy should be aimed at guarantying minimum wage and living wage which assures proper standard of living. In case of retired incomes policy should honest guarantee retirement pension level. This is very hard to be achieved without violation of market rules. One has to notify that pension is, contrary to various unemployment and social benefits, live long benefit. Economic politicians should create incomes policy in this field very carefully, because ease access to retirement plan, especially for earlier benefiters may result in rapid rise of pensioners, which have full working ability that cause heavy burden on social security system. This situation was very common in centrally governed economies, which resulted in high burden on wages raising "tax wedge". ${ }^{13}$

The last task of incomes policy may be stabilization of labor market. Stabilizing is usually aimed on reducing or stopping increase of unemployment rate. In order to do so politicians can rely either on direct or on indirect means. In case of direct means, apart from wages control and minimal wage regulations, subsiding of wages of chosen type of employees (especially young and low skill) and wages policy in the public sector have to be mentioned. If we consider five elements that influence wages proposed by A. Okun: ${ }^{14}$

- standard wage increases;

- wages offered by other employers ;

- prices;

- earnings;

- prices of comodities.

One has to notify that wages offered by other employers should also be referred to public institutions (especially in countries with big public sector). This allows influencing on wages in the private sector by proper wage policy in the public sector. Curbing wages increase in the public sector may

Another method of stabilizing labor market is use of in-direct means. In this case social security system can be widely used. In such situation main aim of incomes policy is reduction of labor supply. However one has to notify that reducing labor supply in this way may result in distortion on labor market due to substitution of wages by social security benefits (especially pensions).

Such situation may result in quite low benefits which enforce young pensioners to work. Big number of young pensioners may result in pushing out young employees of labor market or result in reduced wages for them. Mechanics of this phenomenon is quite simple.

\footnotetext{
12 see G. S Fields, Who Benefits from Economic Development? - A Reexamination of Brazilian Growth in the 1960's. . American Economic Review, 1977, Vol. 67 Issue 4, pp. 570-582.

${ }^{13}$ See Z. Czepulis-Rutkowska, Systemy emerytalne a poziom zabezpieczenia materialnego emerytów, IPiSS, Warszawa 2000, p. 67

${ }^{14}$ A. Okun Ceny i ilości analiza makroekonomiczna, PWN Warszawa 1991, p. 122.
} 
For employer it is quite economically viable to employ young pensioner due to two main reasons. First is possibility to acquire such employee at relatively low wage (because wage is an extraordinary income for pensioner). Another important element of this is fact that usually employment of pensioner eliminates need of paying various social security burdens which makes such employee even cheaper.

However there's negative side of this solution. Newly entering labor market have to accept lower pay rates and in the future lower pensions.

Analyzing economy under transition requires considering this fact, because in the centrally run economy this was very common situation. Planning commission used social security system in order to create jobs for younger employees. The example of so defined policy in case of Poland is shown below.

In Poland only for the period between 1970-1980 the number of disability benefit doubled from 2,3 million do 4,7 million. Yearly average number of such benefiters rose by 240 thousnad. ${ }^{15}$ Additional data for chosen years for the period $1965-1990$ is presented in the table 1.

Analysis of data from table 1 shows that share of social security benefits was quadropouled over 25 years. This of course resulted in need of raising contribuition to social security system. This was first but not most important negative result of treating incomes policy as a tool for labor market stabilization.

Table 1 Personal Incomes in the selected years in the period $1965-1991$ (\% gross income)

\begin{tabular}{|l|l|l|}
\hline \multicolumn{1}{|c|}{ Year } & \multicolumn{1}{|c|}{ Incomes form labor } & \multicolumn{1}{c|}{ Social security benefits } \\
\hline 1965 & 58,8 & 4,5 \\
\hline 1970 & 57,7 & 9,8 \\
\hline 1978 & 56,8 & 10,4 \\
\hline 1985 & 47,8 & 15,4 \\
\hline 1988 & 45,8 & 15,5 \\
\hline 1989 & 45,7 & 15,9 \\
\hline 1990 & 36,4 & 17,5 \\
\hline
\end{tabular}

Source: Ubóstwo w Polsce w 1992 Roku, J. Hrynkiewicz, W Sierzputowska, Kancelaria Sejmu Raport nr 18, BSiE, Warszawa 1992.

The most important result of such activities was common acceptance of granting social privileges to various groups of citizens. More over usually granting them took place without economic explanations . Treating early retirement or disability benefit as normal source of income was serious obstacle that slowed down transition.

If one continue analyzing table 1 it can notify two periods of strong increase of social security benefiters. First took place in the years 1965-70 when number of them doubled Another sharp rise can be observed between 1978-85, when number of benefiters rose by $100 \%$ again.

${ }^{15}$ W. Muszalski op. cit. p. 76. 
Figure 2. Personal Incomes in the selected years in the period $1965-1991$

(\% gross income)

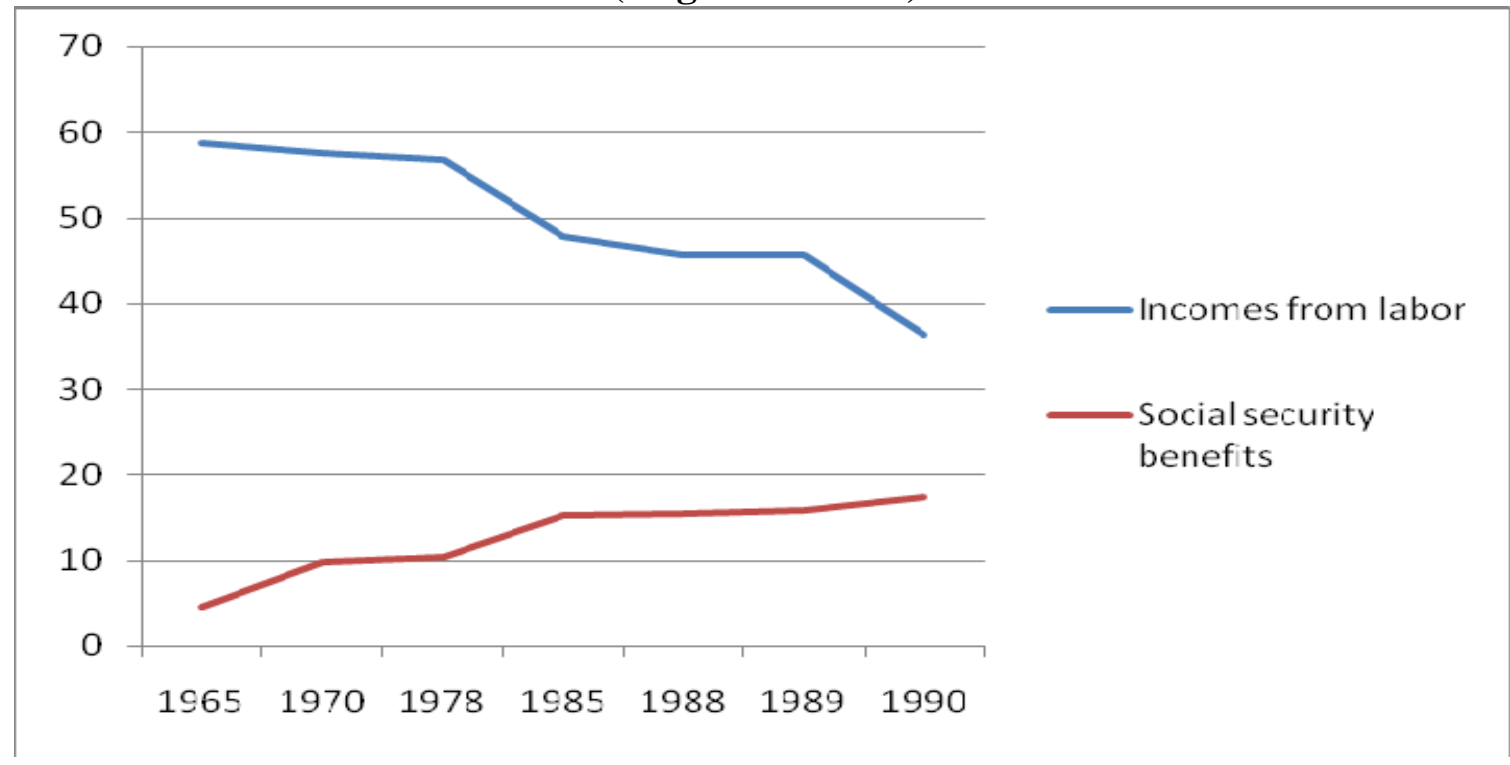

Source: Author's own on the basis on table 1

Sharp rise in number of benefiters can be explained by legal regulations concerning pensions. By 1983 there was joint pension system with fixed retirement age for men set at 65 years and for women 60 years. ${ }^{16}$ There were some exemptions from this rule, however they were not common. Due to poor condition of economy, a major change of this rule took place in the first half of eighties, was introduced.

One of the major impacts that boosted changes were strikes of 1980. On August 17th, 1980 Inter enterprises Strike Committee announced. They had mainly political character considering such issues as registration of free labor unions, one has to remember that economic issues, such as wages increase ar supply improvements were also mentioned. But for the analysis of economic policy crucial was demand no. 14 which stated: lowering retirement age to 50 years for women and 55 for men Or assuring pensions for people with 30 years of work in case of women and 35 for men ${ }^{17}$.

This was very important sign describing social conditions and philosophy about understanding of economy by citizens. Tomorrow it is very hard to clearly explain whether these demands were element of pressure on communist government or real expectations. Undoubfully this way of attitude towards economic issues influenced economic policy over next 30 years.

After martial law introduction government tried to improve situation by various means, however without dismantling centrally run economy and political system. Of course introducing radical solutions in the economy was impossible so instead of this administration decided to create appearance of improvements in economy.

First move was granting right to earlier retirement in 1981-1982 for employees aged 55 (men) an 50 (women) which resulted in increase of retired by 500 thousands instead planned 150. As a result economy suffered from lack of labor force ${ }^{18}$

Moreover pension calculated on this basis accounted for $90 \%$ of pension awarded on

\footnotetext{
${ }^{16}$ See Ustawa z dnia 14 grudnia 1982 o zaopatrzeniu emerytalnym pracowników i ich rodzin, Dz. U. Nr 40, poz. $\frac{267}{17}$

${ }^{17}$ http://www.solidarnosc.org.pl/archiwum/historia/21 post.htm, 27.02.09.

${ }^{18}$ W. Muszalski, Wprowadzenie do nauki ubezpieczenia społecznego , PWE Warszawa 1998, p. 77.
} 
the basis of common regulations.${ }^{19}$ However one has to remember that granting do big privileges to place only once. Much more consequences for incomes policy stemmed form regulations introduced in the 1983 which granted early retirements (with retirement age of 60 for men and 55 for women) plan. ${ }^{20}$ All professions listed in the appendix to government bill were allowed to get earlier retirement. The biggest problem of this regulation was fact that professions were listed without any medial analysis that could explain why they were subject to earlier retirement.

\section{Conclusion}

On the basis of above presented definitions of incomes policy and its goals, one can say that in case of country under transition it can have much different meaning that classical incomes policy its targets are much wider and complicated. More over it shows that curbing inflation is not only goal for incomes policy.

\section{REFERENCES}

1) Adam Inflacja a bezrobocie. „Ekonomista” nr 4-6, 1991.

2) Ashenfelter O., Layard R. , Incomes policy and Wage differentials , "Economica", may 1983.

3) Barczyk R., Teoria i praktyka polityki antycyklicznej, AE Poznań 2004,

4) Bean Ch. R., The role of demand policies in reducing unemployment. [in]: Unemployment policy :government options for the labor market ed. D. Snower, G. de la Dehesa, Cambridge University Press, 1997.

5) Borkowska S., System wynagrodzeń w skali makro, Instytut Pracy i Spraw Socjalnych, Socjalnych, z. 10. Warszawa 1991.

6) 6.Czepulis-Rutkowska Z., Systemy emerytalne a poziom zabezpieczenia materialnego emerytów, IPiSS, Warszawa 2000.

7) G. S Fields, Who Benefits from Economic Development? - A Reexamination of Brazilian Growth in the 1960's. . American Economic Review, 1977, Vol. 67 Issue 4.

8) Kessler S., Incomes Policy, British Journal of Industrial Relations , Vol .32 nr 2, June 1994 .

9) Meller J., Makroekonomiczna polityka wynagrodzeń w gospodarce rynkowej, „Praca i zabezpieczenie społeczne”, nr 10/11 1992.

10)Muszalski W, Wprowadzenie do nauki ubezpieczenia społecznego , PWE Warszawa 1998

11)Okun A. Ceny i ilości analiza makroekonomiczna, PWN Warszawa 1991.

12)Szopa B. , Polityka dochodowa na tle rynku pracy w Polsce w warunkach transformacji systemowej, AE Kraków 1997

13)Weintraub S. TIPs against Inflation, [w:] An incomes policy for the United States, ed. M.P. Claudon, R.P. Cornwall, Martinus Nijhoff Publishing, Boston, 1981.

14)Winiarski B., Polityka gospodarcza, PWN Warszawa 2006.

\footnotetext{
19 See:ozporządzenie Rady Ministrów z dnia 17 lipca 1981 r. w sprawie szczególnych zasad przechodzenia na emeryturę pracowników uspołecznionych zakładów pracy w okresie do dnia 31 grudnia 1981 r., Dz. U. 1981, nr 19, poz. 95.

${ }^{20}$ See: ozporządzenie Rady Ministrów z dnia 7 lutego 1983 r. w sprawie wieku emerytalnego pracowników zatrudnionych w szczególnych warunkach lub w szczególnym charakterze (Dz. U. 1983 Nr 8, poz. 43)
} 
15)Ustawa z dnia 14 grudnia 1982 o zaopatrzeniu emerytalnym pracowników i ich rodzin, Dz. U. Nr 40, poz. 267,

16)Rozporządzenie Rady Ministrów z dnia 17 lipca 1981 r. w sprawie szczególnych zasad przechodzenia na emeryturę pracowników uspołecznionych zakładów pracy w okresie do dnia 31 grudnia 1981 r., Dz. U. 1981, nr 19, poz. 95.

17)Rozporządzenie Rady Ministrów z dnia 7 lutego 1983 r. w sprawie wieku emerytalnego pracowników zatrudnionych w szczególnych warunkach lub w szczególnym charakterze (Dz. U. $1983 \mathrm{Nr}$ 8, poz. 43)

18)http://www.solidarnosc.org.pl/archiwum/historia/21 post.htm, 27.02.09 